Article

\title{
The Philosophy of Freedom and the History of Art: An Interdisciplinary View
}

\author{
Robert Edward Gordon (D) \\ College of Fine Arts, The University of Arizona, Tucson, AZ 85719, USA; regordo1@arizona.edu
}

Received: 1 May 2020; Accepted: 26 August 2020; Published: 1 September 2020

\begin{abstract}
This article investigates the relationship between the philosophy of freedom and the history of art. It maintains that contemplating the two fields together is productive and necessary in understanding some of the compelling interdisciplinary aspects at work in both arenas. Isaiah Berlin's seminal Two Concepts of Liberty (1958) acts as a touchstone, as the essay establishes the historical and political grounds for uniting the two fields, with other thinkers contributing to the analysis. The ideas discussed correlate the history of art as a narrative of creativity and freedom with art's political function as it pertains to the positive-negative liberty perspective. These two forces offer a fecund way of thinking about freedom and the arts co-terminally. This essay argues that the creative motivations embedded in the history of art are intimately linked to political motivations, which it is claimed tie the two subjects together both historically and philosophically.
\end{abstract}

Keywords: freedom; liberty; art; history; Berlin

\section{Introduction}

The multifaceted debates about freedom address a number of broad themes, among which include how freedom relates to other values such as equality, freedom and determinism, freedom and moral responsibility, and the nature of freedom itself, as expressed in the difference between positive and negative liberty [1]. The scope of freedom as a subject of philosophical inquiry inspires me to approach the topic from my own area of expertise: the history of art. The question motivating this essay is: can art history—particularly visual art—say anything of value about freedom as a philosophical concept?

Certainly, art historical artifacts exist that address the theme of freedom, as with Jacques-Louis David's eighteenth century revolutionary paintings, Delacroix's Liberty Leading the People (1830), Rockwell's Four Freedoms (1943), or Ringgold's Freedom of Speech (1990). However, art history's goal is to establish facts, interpret meaning, and form narratives. Ascertaining the philosophical precepts for the conditions for liberty is beyond its compass. Investigating the two subjects together, then, might seem somewhat arbitrary. Interdisciplinary discussions such as this often retain that tenor. Moreover, the two fields are exceedingly large, and one could never hope to address their full scope adequately. Nevertheless, I contend that there is good reason to reflect upon freedom from an art historical perspective, something that is not prevalent in the ongoing philosophies of freedom in the liberal tradition. I believe that the association of artistic and liberal qualities as they have manifested themselves throughout human history is proximate enough to justify thinking through the two concepts together. Doing so is helpful, it seems to me, in understanding some of the compelling interdisciplinary aspects at work in both arenas.

\section{Argument}

This essay looks at freedom and the arts through the lens of positive and negative liberty ("freedom to" and "freedom from", respectively), highlighting their relationship to social and political discourse 
as understood through the prism of history. Isaiah Berlin's seminal text Two Concepts of Liberty [2] (TCL hereafter) is situated in form and content to offer insights as to how the artistic and political relate to the historical and philosophical discussion of liberty. Given its ongoing relevance in the field, this essay utilizes the text in many areas, but brings in other thinkers to countenance various aspects of the topic as they emerge. My overall argument and observation is that the notions of positive and negative liberty have been a key dynamic at work in art's historical advance, its production, and its subject matters broadly construed. A major assertion of my argument in this respect has to do with the political, social, and artistic impetus for creating artwork in order to influence the masses. As examined below, the creative motivations embedded in the history of art are intimately linked to political motivations, which I claim tie the two subjects together both historically and philosophically. The nature of art changed in the modern era, starting with the Enlightenment, as the direction of artistic force moved from the powerful to the general public. Art's ability to influence society did not change, but the vectors with which that force was applied underwent a profound shift. The ideas discussed below correlate the history of art as a narrative of creativity and freedom with art's political function as it pertains to the positive-negative liberty perspective. In particular, it is the political power that governments have wielded over those they have ruled-whether democratic, monarchical, ecclesiastical, or imperial — that becomes salient, and how the arts have contributed to that power as a force of both legitimation and contestation.

Let me say at the outset that in order to warrant such sweeping claims about art history, one must necessarily take a meta-level view of the field. Yet, as I see it, a top-down view is defensible in this case. As a discipline, the history of art has traditionally been one of understanding particular artifacts and trends and formulating them into a larger historical framework. The periodization inherent in constructing a cogent account of history-while problematic in some ways-is nonetheless still a valid and useful method of understanding a multifarious array of facts and viewpoints. Such is not the general practice in philosophy. Even inductive arguments rely on distinctions that tend to narrow down broad assertions in order to ensure rational integrity. Discipline-specific studies and microhistories have intrinsic internal mechanisms that serve as delimiting boundaries that likewise operate to minimize expansive generalizations. In this discussion, the wide-ranging scope of my assertions are qualified by limiting the argument primarily to the positive-negative view of liberty, and by adhering as closely as possible to the accepted definitions common to the philosophy of freedom. In keeping with much of the existing literature, I use the terms "liberty" and "freedom" interchangeably. Some philosophers make a distinction among the terms freedom, liberality, and liberty. For these thinkers, freedom refers explicitly to political freedom-deriving from the Greek term eleutheros (unrestrained), liberality to characteristics of free individuals, and liberty to positive or metaphysical freedom ([3], p. 131). However, my analysis arcs across all of these connotations.

Roughly, positive liberty entails the ability of individuals to act autonomously as a function of self-mastery; the self-determined freedom to do and self-actualize inherent in one's ontology. According to Berlin, it is involved with the question "What, or who, is the source of control or interference that can determine someone to do, or be, this rather than that?" Negative liberty refers to the constraints placed against individuals to act in some manner; the absence of obstacles imposed from without. As Berlin states, it answers the question "What is the area within which the subject-a person or group of persons-is or should be left to do or be what he is able to do or be, without interference by other persons?" ([2], p. 7). When a positive liberty theorist seeks to determine whether people are free, "the focus is what they have done or how they have done it. A proponent of negative liberty asks not what they have done but whether they are unprevented from doing something" ([4], p. 3). What we find is that, in many ways, these conceptions of liberty are two sides of the same coin of human agency. The political questions they address bifold, or "overlap", as Berlin states ([2], p. 7). In the positive liberty sense, the human spirit is a horse that wants to run, as it were. It inherently wants to move, to do, to act. The foremost reason it cannot is if some external, negative liberty force 
prevents it. These two forces, united as they seem in their influence on human affairs and our innate desire to act, offer a fecund way of thinking about freedom and the arts co-terminally.

Berlin was a negative freedom advocate, believing that negative liberty doctrines are more humane and truer to the reality of governing a world where a multiplicity of desires and goals exist coevally. Yet, some thinkers are not fully convinced of the primacy of the positive-negative binary he foregrounds in TCL. C.B. MacPherson argues that Berlin's view of liberty "empties too much out of negative liberty", that it excludes withholding the means of life or labor by an external force ([5], p. 117). He suggests an alternative to Berlin's negative liberty that he redefines as "counter-extractive: an immunity from the extractive power of others" and favors referring to positive liberty as "developmental liberty". Others, such as Quentin Skinner and Philip Pettit, forward "Republican Liberty" as an additional type of freedom as relevant, where political liberty with respect to dependency, non-domination, and the absence of arbitrary power are primary issues [6]. Nevertheless, even with the many challenges to Berlin's account of the positive-negative binary, this bifold conception of freedom has remained a compelling framework on the subject, as it seems to comport to our common sense notions of what freedom entails in many walks of life.

\section{The Autonomy of Art}

When art and freedom are addressed together, aesthetic considerations have played a big role in the discussion in terms of their prominent political dimensions. A secondary issue, thus, emerges as to whether the philosophical notions of positive and negative freedom can say anything about aesthetics, or conversely, to what extent do aesthetic issues reference freedom. By "aesthetic", I mean theories of art that include not only notions of the sublime and the beautiful, a traditional connotation of the term since the eighteenth century ([7], p. 6). For the philosophical issue at hand, it may be whether there are certain judgements involved in the political history of art that would constitute any sort of coherent aesthetic thinking.

Not everyone privileges the close connection between the political and the artistic argued for here. Jacques Rancière, for instance, has forwarded an equality driven theory of art- "the distribution of the sensible"-stemming from a Platonic view of cultural production made of various "regimes". While trying to locate freedom in Rancière's ideas of equality, Rika Dunlap states, "His position is that the significance of art is political in nature, yet art maintains its autonomy from other aspects of life, including politics". Thus, "a paradox emerges in understanding the significance of art: Art is art as long as it is political, but art is art when it is divorced from politics" ([8], p. 342). Art and politics create the sensible world for Rancière, but aesthetics is a self-referential regime that "simultaneously establishes the autonomy of art and the identity of its forms with the forms that life uses to shape itself" ([9], p. 23). Rancière's paradoxical binary seems to both reinforce and contradict my assertion as to the significance that political motivations have played in the history of art. He acknowledges the strong political nature of art in general, but holds the ultimate autonomy of art as a priority. Setting aside Victor Cousin's famous phrase "art for art's sake", one can understand how that might be if only on formalist grounds. Critics such as Clement Greenberg and others have argued that since the mid-nineteenth century modernism was essentially a self-critical condition, that modern art derived its quality and autonomy as a function of its formal properties. In Greenberg's view, modern art's historical path progressed as it explored its media's limitations, "not in order to subvert it but in order to entrench it more firmly in its area of competence" ([10], p. 85). Similarly, Marxists such as Lukács and Adorno frame the political discreteness of art's function in socioeconomic terms: the autonomy aesthetic "is conceived as a social realm that is set apart from the means-ends rationality of daily bourgeois existence" ([11], p. 10).

The notion of art's autonomy is an important one. But this autonomy does not preclude its place in political life. Indeed, for Rancière, art and politics also "construct and modify the common sensible world" in which they inhabit ([8], p. 342). Yet, I believe Rancière's "paradox" points to a built in uncertainty about whether art can ever really be autonomous. After all, we live and art exists within a society, regardless of its theoretical aspirations or social distinctiveness. For Adorno, 
"To describe art as autonomous is not to attribute to it a reality outside history or society" ([12], p. 173). To assuage its paradoxical nature, it is essential here to distinguish between the fine arts-the creation of paintings, sculpture, classical music, and even architecture-from the history of the arts, which includes not only the timeline of events, but also the social and political purposes in their creation. Artists have long created works of their own private inspiration. But the history of art-the artifacts that continue to last throughout the ages, particularly those artifacts commissioned by the powerful, as the great majority of historical works have-takes on a larger significance. Once the artist's work becomes widely known and accepted as a significant example of human creativity, it transcends the individual artist and enters into a broader historical narrative. It becomes part of "culture" writ large. Artworks become national treasures (think of the various national galleries). Artists receive nationalist awards (e.g., Andrew Wyeth received the Presidential Medal of Freedom in 1963). Important architectural complexes and monuments become "World Heritage Sites". The most significant art "belongs to the world" in a real way, a sentiment echoed by the 2019 Berresford Prize awardee Kristy Edmunds [13]. It is in this sense, therefore, that I implement the political nature of art, as a separate but not autonomous mode of intercourse. An artist may create art without intending any overt political purposes. He or she may create an untitled abstract work devoid of narrative or representation. One may be able to appreciate an artwork without reference to anything else but the artwork alone. However, there is still a sense that any intended autonomy is contingent with respect to its historical quality. As Adorno states, "The Hegelian vision of the possible death of art accords with the fact that art is a product of history" ([14], p. 4). The old art historical adage that "art is a reflection of its time" continues to retain an elemental truth.

\section{Freedom and Art}

When talking about freedom with respect to the arts, especially the visual arts, the discussion often focuses on "artistic freedom". The political ability of an artist to create as he or she sees fit without fear of societal or governmental condemnation or reprisal is an important outgrowth of the modern philosophical debates on freedom. Here, the positive-negative liberty debate is a vital aspect. It is a topic that was of particular issue in the West during the twentieth century, where political control and censorship were primary concerns. Indeed, during the Cold War, U.S. intelligence agencies forwarded American art as a symbol of the cultural and creative freedom of democratic nations over that of the communist regimes [15]. Artistic freedom continues to be a global concern. The UN Human Rights Council issued a report in 2013 addressing "the multi-faceted ways in which the right to the freedom indispensable for artistic expression and creativity may be curtailed" ([16], p. 1).

One of the most difficult issues has to do with art that is commissioned by public institutions, and whether the artwork-especially controversial art-can be censored from public display. The situation is complicated. Today, artists strongly lionize negative liberty "freedom from" doctrines, decrying any government restrictions on the creation, exhibition, and treatment of challenging artwork in public museums. Recent permutations of this argument even include "freedom from financial and logistical constraints such as museum budgets and exhibition deadlines" ([17], p. 355). Modern and contemporary artists also champion the positive liberty that animates their counter-cultural, anti-conventional, non-traditional disposition, which has yielded unquestionable artistic achievements. Artists insist on the "freedom to" create artwork even with the strong intention to incite outrage, as with Andres Serrano Piss Christ (1987) photograph of a crucifix submerged in his own urine. Another example is Dread Scott's 1988 What is the Proper Way to Display a U.S. Flag? which asks viewers to stand on the American flag while writing a response to the question. On the other hand, some judgment must be made when determining what sort of artworks are displayed, particularly when tax dollars have subsidized either the artwork or museum. Public institutions retain their own rights and claim the "freedom to" curate exhibitions as they see fit, "free from" coercion.

In exploring these bifold aspects of positive and negative freedom, Berlin's Two Concepts of Liberty continues to play a prominent role in the philosophical debates on the subject. Published in 1958 
during the Cold War, its substance is historical, exegetical. TCL is framed within the sociopolitical implications of philosophy during the era. According to Berlin, a firm understanding of the two conceptions of freedom and their philosophical ramifications is not merely academic, for "there has, perhaps, been no time in modern history when so large a number of human beings ... have had their notions', and indeed their lives, so deeply altered, and in some cases violently upset, by fanatically held social and political doctrines" ([2], p. 3-4). Yet, John Gray also claims that Berlin "was never primarily a "Cold War thinker'" ([18], p. 6). Although he was a political philosopher at Oxford, artistic ideas actually weighed heavily on his mind. In a 1992 discussion about his career with his biographer Michael Ignatieff, he confessed that "Politics are not the center of my thought. The center of my thoughts were literature, the arts, and people" ([19], (17': 37-42').

The bulk of TCL is geared toward explicating and undermining positive freedom doctrines as "a specious disguise for brutal tyranny" ([2], p. 16). Berlin makes clear that the negative notion of liberty is essentially political, focused mainly on the non-interference of people in positions of control. This is consistent with earlier conceptions of political freedom, as with Mill's conception in On Liberty (1859) as the historical struggle between liberty and authority, what Mill calls "Civil, or Social Liberty: the nature and limits of the power which can be legitimately exercised by society over the individual" ([20], p. 73). To the extent that coercion is exercised from without in restricting one's freedom-as opposed to some intrinsic inability-its civic association is of greatest concern to the negative liberty tradition. Berlin writes, "Coercion implies the deliberate interference of other human beings within the area in which I could otherwise act. You lack political liberty or freedom only if you are prevented from attaining a goal by human beings" ([2], p. 7). To be sure, it is clear that to be free does not mean that one can do whatever he or she wants. We all accept laws as understandable constraints on what is called laissez-faire freedom. Freedom in the negative political sense essentially means freedom from an oppressive government. As Mill states, "By liberty, was meant protection against the tyranny of the political rulers" ([20], p. 73). In this regard, the argument between freedom or unfreedom, therefore, hinges on what exactly oppression entails, which can vary from person to person. Broadly speaking, however, the key is to manage the political powers that seek to limit—or allow others to limit—our intrinsic desire to act in a positive manner.

The history of art is not exterior to the ebb and flow of this philosophical environment of ideas. On the contrary, the twofold conditions of liberty are a major undercurrent in the historical development of art as it pertains to human affairs in a political sense. The phrase "political powers" used just above is an important aspect of the below analysis, within which I nuance and blend the concepts of power and politics by placing them as seamlessly associated with one another. For whereas one may be powerful in a non-political sense, it seems unproblematic to conceive of power as the raison d'etre of political engagement.

\section{The Historical Sweep of Art and Liberty}

A key point of historical intersection between the philosophy of freedom and the fine arts occurred in the modern era. For although both fields can trace their intellectual legacies to antiquity, modern philosophical discussions of liberty look back to thinkers, starting with Hobbes and Locke in the 17th century (moving on through Bentham, Rousseau, Kant, Mill, Marx, and others in subsequent centuries [21,22]. In a concurrent development, the beaux-arts (fine arts) were institutionalized in Western political consciousness also during the 17th century, with the formation of the Académie Royale de Peinture et de Sculpture in France, which later came to be known as the Académie des Beaux-Arts ([23], p. 11). Its beginnings, thus, developed at the same time in Europe as the Age of Reason, when the Enlightenment concept of individual liberty developed in the West as a high social and political cause. In fact, French artists and intellectuals founded the Académie to escape the "tyranny" of the powerful artistic guilds extant since the medieval period, and thereby achieve a "freedom of the arts- the right to exercise the profession of painter or sculptor without guild membership" ([24], p. 114). Even in this 
small example, we see the bifold positive-negative liberty dynamic at work, where the artists attained a "freedom to" engage in a profession and thereby achieve "freedom from" a perceived tyranny.

The discursive upshot of these developments is that they situate the philosophical dialogic of freedom and art in thematic accord at the dawn of modern era, where an important historical hinge occurs. Looking back over the broad contours of cultural output from over the last five thousand years reveals that the history of art has been primarily political in nature. It is a prolonged account of the powerful, whether secular, religious, or commercial, using the arts to influence and manipulate the masses as a way to underwrite their positions of privilege and power in society, even into the modern era. As Donald Preziosi writes in his famous The Art of Art History, such a narrative of power speaks to "the diverse ways in which art history may be seen as constituting a social and epistemological technology [original emphasis] which has been essential to the conception, fabrication, and maintenance of (originally European, subsequently all) modern nation states, and of the individual and collective identities that are staged as the supports and justifications for these political entities" ([25], p. 10).

It is fair, of course, to cite instances where this dynamic does not seem to obtain. Zen paintings, for example, seem fairly personal and isolated in terms of their subject matter and audience. And as mentioned above, artists have long created works of their own private inspiration. Yet, it is important to keep in mind that patronage, especially political patronage, has been a tremendous force in the generation of art throughout history. Many artworks and monuments take a great deal of money to create, and for much of human history, only the rich and powerful were in a position to support high level artistic production as they invested in their own interests. A current exhibition at the Metropolitan Museum of Art draws on this history, with objects from across the globe that underline this point:

Patrons in Asia, the Americas, Africa, and Europe-Regions at times connected by trade, diplomacy, and war-commissioned representations in stone, wood, and paint to convey authority and to memorialize acts of devotion. Adorning spaces public and private, these artworks identified centers of political and spiritual power, projected concepts of rule and community, visualized ways of thinking about the holy, and served as sacred gifts. [26]

Moreover, until the modern era, the arts were associated primarily with the highest strata of social standing: royalty, the aristocratic class, the wealthy gentry. The Chinese or Japanese Zen artist may very well have quickly rendered a portrait as a way to experience personal enlightenment, but East Asian Buddhism was closely aligned with the aristocratic literati and ruling classes, and thus, would knowingly place the artist and adherent in a political context. Outwardly inert portraits across the globe have simultaneously memorialized the royal or aristocratic legacies of countless men and women of power. Even seemingly innocent and highly decorous Rococo paintings were created to match the luxurious interiors of the nobility of the French court, and thus, engage in the aesthetics of power. Countless other illustrations exist to support these assertions.

It is also vital to stress that religion has been closely linked to the world's political establishments for most of humanity's cultural history, deteriorating with the Enlightenment-inspired separation of church and state. This point becomes significant inasmuch as the history of art is overwhelmingly religious and has been crucial to the development of aesthetic achievement and its societal significance in this regard. Beauty, metaphor, and symbolism were mechanisms for rulers to unite their political identities with the cosmic forces embodied by the gods. As any art history textbook can attest, Egyptian pharaohs used the arts to reinforce their divine political status as intercessor between the gods and man. The Greeks and Romans found the arts indispensable in establishing their combined religious, philosophical, and political legacies, the stories and myths of which were the foundation of their cultural institutions ([27], p. 15). The Mauryan Emperor Ashoka in the third century BC built commemorative pillars of exquisite craftsmanship to the Buddha and his teachings as a way to fortify his political position and "to provide inspiration and guidance to his descendants and to his people" ([28], p. 1). The Roman Catholic Church-a profoundly powerful social and political force in Europe for centuries-utilized the visual arts' didactic and inspirational efficacy to underwrite both its political and spiritual power. Indeed, Pope Julius II raised and led armies while also rebuilding and 
redecorating St. Peter's Basilica. At the same time, rich and powerful merchants, even powerful artists themselves, throughout the centuries have commissioned secular masterpieces to celebrate their success and formalize their elevated role in civil society. Instances from many other cultures could be provided as well. But what these patterns reveal, by and large, is that for most of civilization, the authority of the arts was directly implemented as a way to legitimize the authority of the ruling classes.

However, all of that started to change in eighteenth century Europe. A shift of tremendous magnitude began in the modern era with the articulation of a political individual that started with Hobbes and matured with Locke, the philosophes, and others. The Age of Reason's emphasis on individual freedom transferred over to the artistic realm as well. A 180-degree shift took place in accord with the democratic liberalism that put "The People" in charge of their political fortunes. Slowly at first, but by the nineteenth and twentieth centuries, the arts began to be used to censure the powerful and challenge authority. With a newfound freedom of spirit, the role of the artist as an individual voice has since been used increasingly to confront entrenched hierarchies and criticize the abuses of the powerful to the succor of the masses. William Hogarth in the eighteenth century, Francisco de Goya and Honoré Daumier in the nineteenth century, and the twentieth century avant-garde in particular are prominent illustrations of this Copernican shift in cultural discourse. Exceptions exist, of course. Aristocratic political patronage in the arts did not cease with the rise of individual liberty. Jacques Louis David, for example, used the arts to help the Third Estate overthrow the monarchy during the French Revolution, but then went on to paint some of his most enduring canvases while propagandizing for Napoleon's imperial ambitions. The Salon and Académies in France and Britain (the latter formed in 1768) retained their aristocratic association with the ruling class, and stood against the modernist movement in nineteenth century European art. Soviet and Maoist Socialist Realism of the twentieth century still saw governments attempting to influence society and mass opinion through the arts. Yet, the die had been cast.

The advent of modernism played the major role in this shift. In fact, Rancière locates his aesthetic regime in time and as synonymous with a complex and disjointed "modernity". Romantics, Marxists, revolutionaries, and avant-garde groups-as representatives of a newly enlightened and emboldened population-led the way in art's ability to influence the political environment, now more so directed against the political, religious, and commercial power structures that had formerly exploited the arts against them. The function of art now as then exists largely as a form of social critique and as a mechanism for raising social awareness [29]. Modernist and avant-garde artists were subversive, using the prestige and elevation of art as an institution against itself, both to legitimate their social criticisms and yet, simultaneously, undermine the traditional modes and methods of artistic validation of the past. As the twentieth century turned, the horrible reality of industrialized warfare and the chaotic actuality of contemporary experience forced many progressive-minded individuals to seek alternative ways of creative expression. Artistic groups such as the Dadaists, Surrealists, Futurists, and other radicals sought unconventional, marginal, unorthodox, even taboo, alternatives in an effort to create another reality than the one that existed. To quote Rancière on the topic:

The aesthetic regime of the arts is first of all a new regime for relating to the past. It actually sets up as the very principle of artisticity the expressive relationship inherent in a time and a state of civilization, a relationship that was previously considered to be the 'non-artistic' part of works of art (the part that was excused by invoking the crudeness of the times when the author lived). The aesthetic regime of the arts invents its revolutions on the basis of the same idea that caused it to invent the museum and art history, the notion of classicism and new forms of reproduction... And it devotes itself to the invention of new forms of life on the basis of an idea of what art was, an idea of what art would have been [original emphasis]. ([9], p. 25)

Avant-garde artists abandoned all forms of conventionality in the face of what they saw as the disastrous consequences of following traditional strictures of social conformity and, most importantly, the consequences of reason and rationality. 


\section{Freedom and Reason}

Thus, the advent of freedom as a humanist cause prompted a wholesale change in the direction of political art and speech. With the negative freedom that came with the Enlightenment-based "rule by the consent of the governed" ethos, empowered artists felt free in the positive sense to challenge the political, religious, and commercial powers at work in determining their quality of material and intellectual life. Interestingly, the Enlightenment apotheosis of rationality cannot fully explain this dramatic shift. Indeed, while Horkheimer and Adorno claim "that freedom in society is inseparable from enlightenment thinking", they also maintain that it is a myth containing the "seeds of its demise" ([30], p. xvi). Under what rubric would individuals allow themselves to be ruled for so long by kings, pharaohs, popes, dictators, and the like? Other than the real desire for subsistence, why would artists and the public comply with these forces? Applying Berlin's analysis, the earlier phase of human history was one more closely aligned with positive liberty doctrines, as people rationally felt that they were free to act, despite the existence of totalitarian/political impediments from without. In part, this is due to the pre-modern notion of individualism, where people primarily identified themselves as part of a corporate whole—a church, a guild, a family—rather than as an autonomous individual ([31], p. 94). Indeed, as Benjamin Constant highlights in his 1819 essay, "The Liberty of the Ancients Compared to That of the Moderns", freedom to the ancient Greek meant collective freedom: the ability to discourse publicly on matters of domestic and international law and policy, often to the complete obeisance of individual rights to the collective mind ([4], p. 16).

A brief recapitulation of Berlin's influential argument against positive liberty helps explain my rationale in highlighting the bifold nature of positive-negative liberty and its aesthetic resonances. In TCL, Berlin is at pains to argue that positive liberty thought in the modern world has used reason as a mode of political control. That once a person realizes that the dictates and institutions of power are ultimately—rationally—in his or her best interest, then they are more than willing to succumb to any authoritarian directives that curtail one's freedom. In fact, once the rationality of these dictates is understood, then one freely acquiesces to them, thinking all along that he or she is freely expressing their own will. They are no longer impediments to action from without, but liberal impulses from within. His analogy of the composer/musician is poignant, where the composer signifies the political power and the player the political subject:

For the musician, after he has assimilated the pattern of the composer's score, and has made the composer's ends his own, the playing of the music is not obedience to external laws; a compulsion and a barrier to liberty; but a free unimpeded exercise. The player is not bound to the score as an ox to the plough, or a factory worker to the machine. He has absorbed the score into his own system, has by understanding it, identified it with himself, has changed it from an impediment to free activity into an element in that activity itself. ([2], p. 26)

The aesthetic metaphor above is effective in emphasizing in analogical form the close relationship between negative and positive liberty, but also with suggesting the proximate connection between freedom and the arts argued for in this discussion.

Recall that I include the political and artistic impetus for creating artwork in order to influence the masses as an essential aspect of aesthetic thinking; that the desire for rulers to convince others that their opinions and dictates ought to be obeyed is a key dynamic in world history. But how does this take place exactly? For according to Aristotle, man is a political animal who is also endowed with reason, and presumably can deduce whether he or she is being controlled or manipulated against their will. The crux of the answer lies in why the arts are so influential, something implicit in their political and sociological use and effectiveness. Here, I make another large-scale claim, but one I believe is accurate upon reflection: the arts' main function is communicative; they attempt to convince and even compel people to feel, think, or believe something. That is just what they do. They do so primarily via metaphoric and symbolic means, the primary mechanisms of language. And, since most actions are predicated on some feeling, thought, or belief, ultimately, the arts engage the human intellect in terms 
of both knowledge and morality. They deal with the mind, body, and soul. The large role that mimesis plays in aesthetic apprehension collapses into this understanding as well. As a person apprehends an artwork and is convinced that he or she is seeing something they recognize from the world, the artist has thereby implanted that vision into the cognitive framework of the viewer. The artist has instilled a belief into the spectator, one with the full force of aesthetic intentionality. Such power has never escaped the attention of those seeking to rule, whether coercively or democratically. To the extent that an artwork is created as an act of personal expression, we must admit that doing so only for oneself, with the intention that no one would ever see or hear the work, is quite a limited proposition, and in any event, falls outside the realm of the history of art or what a political power would desire to endorse.

A return to first principles helps to reinforce these claims. The Oxford English Dictionary defines freedom as "the state or fact of being free from servitude, constraint, inhibition" [32]. Such a definition has explicit negative liberty overtones ("freedom from"), but suggests the presence of an oppressor along the lines that Berlin claims is most associated with the consequences of positive liberty doctrines. With respect to freedom, a second implication of art's communicative and expressive quality is that it represents a positive act of liberty: the physical and cognitive "freedom to" create it, one that-according to Berlin-is susceptible to being commandeered by an external political will. The OED also spells out the many other senses in which we use the terms freedom or liberty, including its figurative, religious, scientific, and historically obsolete usages. Indeed, Berlin refers to it as a "protean word". The point to be made, then, is that these two sides of liberty are contingent on the state of mind of the individual. Much of what the term means in everyday life depends upon how one feels, thinks, or believes in any given situation, which explains the variable aspects the concept retains, as well as the power of the arts to influence the psychological and spiritual disposition of an individual, as the above quote suggests.

This sort of aesthetic influence is not limited to that which the powerful can impose upon the artist, artisan, or the public, but also to the act of ruling itself. A fascinating passage in TCL discussing how social problems have become consistently addressed methodologically like those of the natural/rational sciences highlights this claim. Here, the overarching demands of reason as conceived of by the ruling power transcends the principles of individual freedom:

I may conceive myself as an inspired artist, who moulds men into patterns in the light of his unique vision, as painters combine colours or composers sounds; humanity is the raw material upon which I impose my creative will; even though men suffer and die in the process, they are lifted by it to a height to which they could never have risen without my coercive-but creative- violation of their lives. This is the argument used by every dictator, inquisitor, and bully who seeks some moral; or even aesthetic, justification for his conduct. I must do for men (or with them) what they cannot do for themselves, and I cannot ask their permission or consent, because they are in no condition to know what is best for them. ([2], p. 35)

Berlin's arguments indicate the dangers of positive liberty thinking and underscore the negative liberty argument for safeguards against such abuses through various forms of limited government. However, there are limitations to his analysis. Positive freedom is a hallmark of artistic drive and has not always metastasized into tyranny. In fact, Rancière seems to speak to this sentiment within the context of his regimen of aesthetic thought when he states that, "This aesthetics should not be understood as the perverse commandeering of politics by a will to art, by a consideration of the people qua work of art" ([9], p. 13). Nevertheless, the historical hinge that reversed the direction of artistic force in favor of the ruled over the rulers seems clearly to be a function of the Enlightenment's emphasis on negative liberty.

\section{The Methodology of Freedom}

The notion of methodology touched on above is an important one. This is because the centuries-old issue of how reason and science has impacted traditional notions of life, knowledge, and society still persists today. However, in my view the real question is not how reason qua science has affected 
human well-being, but how its rigorous methodology of positivism and objective truth has permeated virtually all realms of sociological understanding. The arts, as a subjectively oriented field of human endeavor, are embroiled in a binary battle between the value of objective and subjective knowledge and its place in contemporary society [33]. The subject of freedom becomes involved insofar as certain philosophers have sought to quantify or measure freedom, a clear byproduct of the certitude and instrumentalism that positivist science has brought to many spheres of thought. For example, Matthew H. Kramer argues that it is possible to measure one's overall freedom via "a complicated ratio, expressible as ... the square of the range of each person's combinations of conjunctively exercisable freedoms, and the range of each person's combinations of conjunctively exercisable freedoms plus the range of each person's combinations of consistent unfreedoms" ([34], p. 359). Ian Carter also finds value in measuring the degrees of one's "overall freedom" quantitively, distinct from any specific freedoms that might exist [35]. Although Kramer and Carter both espouse negative liberty doctrines, such goals miss the point in my view, and unnecessarily complicate the topic's humanistic character in their effort to fit such a protean concept into a quantifiable structure.

Nevertheless, the desire to objectify freedom leads one to the interesting discussion as to what precisely freedom refers to in the world. Is it more akin to a physical thing, and thus, a suitable subject for scientific study and manipulation? Or even, a property of a thing that one possesses, and is still susceptible to quantitative analysis? Conversely, is it more so an aspect of the mental or spiritual realm, an offshoot of the subjective aspects of human experience? Or can it be both physical and spiritual? A branch of these questions coincides with the long standing determinism-free will debate, with whether free will or metaphysical freedom (the innate ability to make moral or rational choices) is even possible in a universe guided by the deterministic laws of physics. Ian Carter holds that '“freedom' is obviously not like 'atom' or 'quark' or 'butter' or 'banana.' Having accepted this straightforward point, however, it does not seem to me to be a mistake to call freedom a 'thing' that we can 'possess' in virtue of its being a quantitative attribute ... [original emphasis]" ([35], p. 25). If so, then his physicalist notion of freedom seems subject to the deterministic claim that free will or choice, something that seems essential to being free, is ultimately not possible.

From an artistic view, the notion of free will reigns supreme. As a function of positive liberty, the artist believes with the utmost certitude that it is his or her own free and unique inspiration that produces their work. On this view, there is nothing deterministic or physicalist about freedom or the aesthetic impulse (as opposed to the physical presence of artworks in the world). Artistic drive and its effects, i.e., what can be called aesthetic experience, fall within the spiritual or non-physical realm of human affairs. For many philosophers, ultimately, the free will-determinism paradox can be set aside within the reality of daily living. In A Brief History of Liberty, David Schmidtz and Jason Brennan write, "Freedom of the will is not an on/off switch, something you either have or have not. Instead, real-world freedom of the will is an ongoing achievement" ([36], p. 212). This argumentative detour is appealing. It allows for the simultaneous existence of both positive and negative freedom, as it seems to stipulate both. In their opinion, each individual must come to grips psychologically with how best to utilize their ambitions and skills within a free society. In other words, regardless of whether one conceives of liberty as positive or negative, each person must find within themselves the parameters within which they can operate based on their inherent needs, abilities, or desires. For Schmidtz and Brennan, these also include their "anxieties, neuroses, defense mechanisms, and so on". This by-pass may also serve as a useful model for the above arguments. Freedom as a philosophical field of inquiry would do well to pay attention to the cultural discourse that art and its history embody, for to do so helps assuage the positive-negative liberty debate in so far as it underscores that thinking of the two viewpoints independently is ultimately unfruitful.

\section{Conclusions}

The above analysis, in total, demonstrates the strong alignment between the political and the artistic. I have argued that the association of artistic and liberal qualities, as they have manifested 
themselves throughout human history, are immediate enough to justify understanding the two concepts together, something that is not prevalent in the ongoing philosophies of freedom. The argument thus articulated, in the end, does not seem to imply some larger theory of aesthetics. Further research into how notions of individuality, religion, moral agency, and how the epistemological foundations of freedom with respect to the fine arts relate still require much investigation. However, a concluding thought emerges that I think brings many of the above elements together. For a major reason for this close affiliation among the artistic, historical, and the political is that they all are intimately tied to the wider context of civilization and its institutions, with the creative artifacts that form the foundation of our shared humanity. Art and architecture are closely entwined with the formation of cultural institutions, both historically and contemporaneously. The most enduring cultures create the most enduring buildings and artwork to help formalize their existence and legitimize the authority of those who commissioned them. Architecture, painting, and sculpture continue to be a way to represent, solidify, and glorify human institutions, whether political, economic, or legal. Currency, flags, anthems, and monuments like Mt. Rushmore are aesthetic artifacts that communicate and institutionalize political values. In fact, political narratives are often just that: attempts to create an aura of power and inevitability supported by the very words and ideas that aesthetically infused objects can instill in an individual. Indeed, for Rancière, "Politics revolves around what is seen and what can be said about it, around who has the ability to see and the talent to speak, around the properties of spaces and the possibilities of time" ([9], p. 13).

Along these lines, people within the arts and humanities tend to be linguistically oriented. Overwhelmingly so. We believe that words and concepts in themselves have a certain power to illuminate and animate the human soul to objective action. Hence their ubiquitous political use throughout history. In this sense, the arts are essentially interior thoughts transubstantiated into sensible objects, generated to affect society in some way. History is an objective story of time and space, one that blends the bifold notions positive and negative liberty into a unified statement about the world. This aspiration, I believe, is also at the core of our spiritual drive and the freedom it desires.

Funding: This research received no external funding.

Conflicts of Interest: The author declares no conflict of interest.

\section{References}

1. Pavel, C.E.; Schmidtz, D. Introduction. In The Oxford Handbook of Freedom; Oxford University Press: Oxford, UK, 2018.

2. Berlin, I. Two Concepts of Liberty: An Inaugural Lecture Delivered before the University of Oxford on 31 October 1958; Clarendon: Oxford, UK, 1958.

3. Laks, A. Freedom, Liberality, and Liberty in Plato's Laws. Soc. Philos. Policy 2007, 24, 130-152. [CrossRef]

4. Carter, I.; Matthew, H.K.; Hillel, S. Freedom: A Philosophical Anthology; Blackwell Publishing: Malden, MA, USA, 2007.

5. Macpherson, C.B. Democratic Theory: Essays in Retrieval; Clarendon Press: Oxford, UK, 1973.

6. Pettit, P. Keeping Republican Freedom Simple: On a Difference with Quentin Skinner. Political Theory 2002, 30, 339-356. [CrossRef]

7. Wartenberg, T.E. The Nature of Art: An Anthology, 3rd ed.; Wadsworth Cengage Learning: Boston, MA, USA, 2012.

8. Dunlap, R. From freedom to equality: Rancière and the aesthetic experience of equality. Cont. Philos. Rev. 2015, 48, 341-358. [CrossRef]

9. Rancière, J. The Politics of Aesthetics: The Distribution of the Sensible; Rockhill, G., Translator; Continuum: London, UK; New York, NY, USA, 2004.

10. Greenberg, C. Clement Greenberg: The Collected Essays and Criticism; O'Brian, J., Ed.; University of Chicago Press: Chicago, IL, USA; London, UK, 1986; Volumes 1-4.

11. Bürger, P. Theory of the Avant-Garde; Theory and History of Literature, v. 4; University of Minnesota Press: Minneapolis, MN, USA, 1984. 
12. O'Connor, B. Adorno; Routledge: New York, NY, USA; Oxford, UK, 2013.

13. Armstrong, A. Kristy Edmunds Named First Recipient of United States Artists' Berresford Prize. ARTnews. 14 March 2019. Available online: https://www.artnews.com/art-news/news/kristy-edmunds-united-statesartists-berresford-prize-12139/ (accessed on 30 August 2020).

14. Adorno, T.W. Aesthetic Theory; Adorno, G., Tiedemann, R., Eds.; Hullot-Kentor, R., Translator; University of Minnesota Press: Minneapolis, MI, USA, 1997.

15. Cockcroft, E. Abstract Expressionism, Weapon of the Cold War. Artforum 1974, 12, 39-41.

16. United Nations, General Assembly. The Right to Freedom of Artistic Expression and Creativity: Report of the Special Rapporteur in the Field of Cultural Rights, Farida Shaheed, A/HRC/23/34 (14 March 2013). Available online: https://digitallibrary.un.org/record/755488?ln=en (accessed on 12 August 2020).

17. Gover, K.E. Artistic Freedom and Moral Rights in Contemporary Art: The Mass MoCA Controversy. J. Aesthet. Art Crit. 2011, 69, 355-365. [CrossRef]

18. Gray, J. Isaiah Berlin: An Interpretation of His Thought; Princeton University Press: Princeton, NJ, USA, 2013; Revised edition.

19. Berlin, I. An Introduction to the Political Philosophy of Isaiah Berlin Through His Free Writings \& Audio Lectures. 9 January 2014. Available online: http://www.openculture.com/2014/01/intro-to-isaiah-berlinthrough-his-free-writings-audio-lectures.html (accessed on 28 April 2020).

20. Mill, J.S.; David, B.; George, K. On Liberty; Yale University Press: New Haven, CT, USA, 2003.

21. Skinner, Q. On the Liberty of the Ancients and the Moderns: A Reply to My Critics. J. Hist. Ideas 2012, 73, 127-146. [CrossRef]

22. Pettit, P. Made with Words: Hobbes on Language, Mind, and Politics; Princeton University Press: Princeton, NJ, USA, 2009.

23. Harrison, C.W.; Gaiger, J. Art in Theory 1648-1815: An Anthology of Changing Ideas; Blackwell: Oxford, UK; Malden, MA, USA, 2000.

24. Michel, C. The Academie Royale de Peinture et de Sculpture: The Birth of the French School; Chris, M., Translator; Getty Publications: Los Angeles, CA, USA, 2018; pp. 1648-1793.

25. Preziosi, D. The Art of Art History: A Critical Anthology; Oxford History of Art; Oxford University Press: Oxford, UK, 1998.

26. Metropolitan Museum of Art. Power and Piety. Crossroads Exhibition-6 March 2020-Ongoing. Available online: https://www.metmuseum.org/exhibitions/listings/2020/crossroads/power-and-piety (accessed on 30 August 2020).

27. Meier, C. A Culture of Freedom: Ancient Greece and the Origins of Europe; Chase, J., Translator; Oxford University Press: Oxford, UK; New York, NY, USA, 2011.

28. Nikam, N.A.; Richard, M. The Edicts of Aśoka; University of Chicago Press: Chicago, IL, USA, 1959.

29. Best, M.; Baca, M.D. (Eds.) Conflict, Identity, and Protest in American Art; Cambridge Scholars Publishing: Newcastle upon Tyne, UK, 2015.

30. Max, H.; Adorno, T. Dialectic of Enlightenment: Philosophical Fragments (Cultural Memory in the Present); Stanford University Press: Stanford, CA, USA, 2002.

31. Grover, R.A. Individualism, Absolutism, and Contract in Thomas Hobbes' Political Theory. Hobbes Stud. 1990, 3, 89-111. [CrossRef]

32. Freedom, N. OED Online; Oxford University Press: Oxford, UK, 2020. Available online: www.oed.com/view/ Entry/74395 (accessed on 30 April 2020).

33. Pinker, S. Science Is Not Your Enemy. New Repub. 2013, 244, 28-33.

34. Kramer, M.H. The Quality of Freedom; Oxford University Press: Oxford, UK, 2003.

35. Carter, I. A Measure of Freedom; Oxford University Press: Oxford, UK, 1999.

36. Schmidtz, D.; Jason, B. A Brief History of Liberty; Wiley-Blackwell: Chichester, UK; Malden, MA, USA, 2010. 